\title{
The Income Effects of Public Subsidies to Traded Services
}

\section{Donald P. Hirasuna and Glen C. Pulver*}

\begin{abstract}
Examining the effects of four economic development subsidiesfactor tax deductions on capital and labor and subsidies for research and development and labor training-we find that subsidies to the traded servicesproducing sector can raise aggregate real income and lower income inequality in comparison to the same subsidies to the manufacturing sectors. The analysis is conducted with a computable general equilibrium model of a state economy. The model is a specific factor model with 21 different industries and 18 different occupations.
\end{abstract}

\section{INTRODUCTION}

For several decades, employment growth in services-producing industries has outstripped that of the goods-producing sector in the United States. During the period between 1970 and 1990, employment in the services-producing sector increased by nearly 40 million jobs. During the same time period, nonfarm goods-producing employment grew only about four million jobs (see Table 1). This relatively high growth in services-producing employment has attracted the attention of policy makers interested in increasing income within their states (Washington State Community, Trade and Economic Development 1996, Oregon Economic Development Commission 1995).

\section{TABLE 1}

Employment by Sector (000's) and Percent Nonfarm Goods-Producing Employment to Total Nonfarm Private Employment

\begin{tabular}{lllll}
\hline & 1970 & 1980 & 1990 & 1993 \\
\hline UNITED STATES & & & & \\
nonfarm goods-producing & 25,338 & 28,594 & 29,422 & 28,107 \\
$\begin{array}{l}\text { services-producing } \\
\text { percent nonfarm goods-producing employment }\end{array}$ & 45,530 & 62,538 & 85,189 & 87,929 \\
$\quad$ to services-producing employment & & 31.4 & 25.7 & 24.2 \\
\hline
\end{tabular}

Source: U.S. Department of Commerce (1995)

In recent years, the United States has experienced a period of sluggish growth in real income and increased income inequality. Many reasons are offered for this, including changing demand for skilled labor, increased global competition, decreased industrial productivity, and weakened labor unions (Juhn, Murphy, and Pierce 1993; Wood 1994; Baumol, Batey Blackman, and Wolff 1985; Piore 1995). Some observers of current income trends suggest that the slow

*Legislative Analyst, Research Department, Minnesota House of Representatives; and Professor Emeritus, University of Wisconsin-Madison. The authors would like to thank Dr. Andrew Reschovsky, Dr. Ian A. Coxhead, and the anonymous reviewers for their advice and counsel. The opinions expressed herewith do not necessarily reflect those of the Research Department or of the Minnesota House of Representatives. 
growth in real income and increased income disparity are direct results of the rapid growth in services-producing employment (e.g., Bluestone and Harrison 1982). They suggest that services-producing industries generate low-wage jobs and offer little opportunity for increases in economic productivity. Thus, they reason that the current decline in rates of income growth is the expected consequence of increased dependance on services-producing industries (Bluestone and Harrison 1982, 1986).

If the decline in rates of income growth is in fact due to increased dependence on services-producing industries, it might be hypothesized that public subsidies to these same industries will generate less economic growth than similar subsidies to the goods-producing sector. There is little historic research assessing this matter. However, some recent literature raises doubt whether the growth in services-producing industries leads to decreased aggregate real income and increased income inequality when compared to goods-producing industries (Beyers 1991; Porterfield and Pulver 1991; Stabler and Howe 1988; Wood 1994; Computer Science and Telecommunications Board 1994; Grubb and Wilson 1992; Juhn, Murphy, and Pierce 1993).

The purpose of this work, therefore, is to compare prospectively the income effects of subsidies to services-producing and goods-producing sectors through the use of a computable general equilibrium model. The specific analysis examines changes in state level aggregate real income and income inequality due to public subsidies awarded to either sector. The four subsidies studied are: a factor tax deduction on capital; a factor tax deduction on labor; a research and development subsidy; and a labor training subsidy. These are public incentives provided by states throughout the United States (Haigh 1989; Isserman 1994). The explicit hypothesis addressed is that public subsidies to services-producing industries result in lower rates of growth in aggregate real income and increased income inequality in comparison to growth in goods-producing industries.

The first section of the paper reviews previous research on the income consequences of growth in services-producing industries. This is followed by an explicit description of the economic model, including the underlying assumptions, specific equations, and methods of impact analysis. The data sources and the methodology employed in aggregating industries are also included in this section. This is followed by a summary of results and policy conclusions.

\section{BACKGROUND}

There is considerable debate in the literature regarding the income consequences of services-producing industries. In earlier years, research suggested little gain in income and possibly an increase in income inequality related to increased employment in services-producing industries. However, recent research suggests the possibility of an alternative view. The historical research may have dissuaded state officials from offering subsidies to services-producing industries. The more recent research raises the question of how economic development assis- 
tance compares with respect to manufacturing industries.

\section{SERVICES, EXPORTABILITY, AND AGGREGATE INCOME}

In the past, it has been suggested that the output of services-producing industries could not be exported and thus these industries were incapable of generating economic growth in a region. There is evidence that some servicesproducing industries are traded over relatively short distances or, as some put it, non-traded (Parsley and Wei 1996). Examples of non-traded service industries include beauty salons and dry cleaners. Consistent with this research are the recent studies that suggest that some are tradeable over longer distances (Beyers 1991; Porterfield and Pulver 1991; Stabler and Howe 1988; Wood 1994). Examples of traded industries include engineering, architectural and surveying services and research, development and testing services. The discovery that some servicesproducing industries are tradeable leads to the possibility that growth in these industries may lead to increased income. However, these studies say little about the impact on aggregate income in the region.

\section{SERVICES, PRODUCTIVITY, AND AGGREGATE INCOME}

It is often suggested that the jobs generated by growth in servicesproducing industries are, by their very nature, bound to produce lower aggregate income (Baumol, Batey Blackman, and Wolff 1985). It is contended that they experience few increases in productivity whereas goods-producing industries are able to develop new technology that generates more output per unit of input. Baumol, Batey Blackman, and Wolff (1985) also state that some servicesproducing industries are asymptotically stagnant and over time become nonproductive. For example, after the development of computer software, only qualitative changes can be made instead of improvements leading to increased productivity.

A recent study by the Computer Science and Telecommunications Board (1994) concludes that in the 1970s the productivity of some services-producing industries lagged behind other industries. The Board notes that there are several potential reasons for slowed productivity growth-regulation of the services-producing sector, overinvestment in information technology, and advances in the quality of services-producing items rather than output. However, the Board leaves open the possibility of matching productivity increases in the goods-producing sector.

\section{SERVICES AND THE DISTRIBUTION OF INCOME}

The literature is not clear on just how much of the current increase in income inequality is a consequence of the growth in dependency on servicesproducing industries. Cutler and Katz (1992) state that a key factor in growing income disparity is an increase in wage inequality. Some scholars suggest that the growing wage inequality is caused by deindustrialization (Bluestone and Harrison 1982, 1986). Through stagnating goods-producing employment and 
decreased unionization, workers are forced to leave goods-producing industries to take low-skill, low-wage employment in the services-producing sector. Although there is some growth in high-skill employment, it is believed that much of the employment growth is in the lower-skilled and semiskilled occupations.

Several recent studies suggest that employment shifts away from well paid manufacturing jobs are not the primary cause of greater wage inequality (Davidson and Reich 1988; Grubb and Wilson 1992; Bound and Johnson 1992; Juhn, Murphy, and Pierce 1993; Freeman and Katz 1994). Grubb and Wilson (1992) conclude that despite the dramatic shifts in employment structure and earnings differences among industries, growth in services-producing employment made only a small contribution to changes in overall inequality. Freeman and Katz (1994) state that the loss in blue-collar manufacturing jobs accounts for as much as one-quarter to one-third of the rise in wage inequality.

Several scholars conclude that shifts in demand for skilled labor cause much of the rise in inequality (Grubb and Wilson 1992; Bound and Johnson 1992; Juhn, Murphy, and Pierce 1993; Bound and Holzer 1993). Wages and employment for highly educated workers increase relative to lesser educated workers. In addition, wages for experienced workers rise compared to wages for persons with less years of experience. Berman, Bound, and Griliches (1993), Murphy and Welch (1993), and Gittleman (1994) suggest that the demand for high-skill occupations has risen relative to the demand for occupations requiring fewer years of education. In addition, some of these studies find that a considerable proportion of services-producing jobs are within high-wage, high-skill occupations (Juhn, Murphy, and Pierce 1993; Grubb and Wilson 1992).

Others suggest that some of the increase in wage inequality is a consequence of changes in international trade (Sachs and Shatz 1994; Wood 1994). They suggest that decreased barriers to trade can cause prices to move toward a single equilibrium price. Price convergence then leads to equalization of factor prices for low-skilled and high-skilled labor. Equalization in factor prices results in less dispersion in wages within developing countries and a wider dispersion in wages in developed countries (Wood 1994). Some economists question the restrictive assumptions required to satisfy this factor price equalization theory. They suggest that assumptions such as identical technology and tastes and no factor reversals seem implausible (Burtless 1995; Bhagwati and Dehejia 1994; Freeman 1995).

In sum, recent research indicates that services-producing industries are capable of generating increased income. It is not clear, however, whether they are capable of productivity increases sufficient to match those created by goods-producing industries in the past. If the reasons for slowed productivity growth in the services-producing sector continue into the future, then it remains plausible that the increase in dependency on services-producing industries corresponds to a reduced rate of aggregate income growth. The literature also indicates that the current increase in income inequality may be a consequence of a number of variables, most related to shifting wages. Finally, the question is left open as to 
whether economic development incentives to services-producing industries will lead to less aggregate income and greater income inequality.

\section{THE COMPUTABLE GENERAL EQUILIBRIUM MODEL}

A state level computable general equilibrium (CGE) model is used to examine the comparative income effects of subsidies awarded to servicesproducing industries and those awarded to goods-producing industries. Data from the state of Wisconsin is used in constructing the model. Since Wisconsin is in many ways a unique state, the results from this study may not be applicable to all other states. Although not a perfect model of all states, Wisconsin is experiencing shifts in services-producing employment and income similar to that of most other states in the country.

CGE models are criticized by some because of simplifying assumptions. For example, the model considers only ceteris paribus results. Outside shocks to the model, like welfare-to-work legislation, may alter actual outcomes from the model's experimental results. Also, economic models require assumptions regarding price adjustments or, in the case of this model, an immediate adjustment to prices. Of course, this may be wrong. For example, fixity in production processes could vary the time of adjustment in ways different from the model. ${ }^{1}$ However, all economic models fall subject to similar problems with assumptions. This model serves as an analytical tool that provides information regarding potential changes in income and income inequality.

This CGE model includes twenty-one industries and eighteen occupations (see the appendix for a list of industries and occupations). For purposes of analysis, consumers are divided into three groups. The CGE model is shocked by each of the four subsidies, first to manufacturing and then to traded services industries, and comparisons are made of their ultimate income consequences. Manufacturing industries are chosen to represent the goods-producing sector because they are frequent beneficiaries of state economic development policies. Traded services are selected to represent the services-producing sector because of their potential exportability and thus the likelihood that they will be the targets of expanded state subsidies. Gini coefficients are used in the income distribution analysis.

The CGE model constructed for this analysis is in the Johansen class (Dixon et al. 1982). The characteristic that distinguishes a Johansen model is that it is written as a system of linear equations in proportionate change form. That is, instead of writing $Y=f(X)$ where $Y$ is vector of endogenous variables and $X$ is a vector of exogenous variables, the Johansen model writes

$\hat{Y}=\epsilon \hat{X}$ where the "^" notation represents proportionate change (i.e., for an individual term $y_{\hat{i}}=\frac{d y_{i}}{y_{i}}$ ) and $\epsilon$ is the matrix of elasticities of $Y$ with respect to $X$.

${ }^{1}$ Another example is that states may retaliate with economic development policies. While this is often discussed, it is not considered in this analysis because some researchers question the empirical relevance of retaliatory responses between states (Hanson 1993). 
Within the elasticity matrix, an individual elasticity of $y_{i}$ with respect to $x_{j}$ equals $\epsilon_{\mathrm{xij}}=\frac{\partial \mathrm{y}_{\mathrm{i}}}{\partial \mathrm{x}_{\mathrm{j}}} \frac{\mathrm{x}_{\mathrm{i}}}{\mathrm{y}_{\mathrm{i}}}$ For example, suppose $\mathrm{Y}$ is a vector of income, wages, consumer demand, and other endogenous variables. Suppose $X$ is a vector of tax rates and other exogenous variables. Under the Johansen form, one can solve for the proportionate change in $\mathrm{Y}$ given a proportionate change in $\mathrm{X}$ by taking the inverse of the elasticity matrix. ${ }^{2}$

\section{ASSUMPTIONS}

The following assumptions help match the model with a regional economy:

A1. Nonexportable services are non-traded services. Some servicesproducing items are purchased locally. Hair cuts, home repair services, and groceries are examples of non-traded services. The assumption places nonexportable services within a modeling framework consistent with the international trade literature (e.g., Cassing and Warr 1985). ${ }^{3}$

A2. Demand for tourism from outside the state is perfectly inelastic to changes in the level of prices within the state. The model assumes that outof-state tourists do not monitor price changes within the state. Although this price monitoring may be common for international tourists who follow changes in the exchange rate, or for tourists visiting large cities like New York, it seems less likely for tourists visiting many states in the U.S. The fact that information on consumer price indexes are not widely distributed may serve as evidence that state-to-state tourism is not widely sensitive to small fluctuations in local prices.

A3. The state economy is characterized by a small open economy with costless transactions in traded goods and services and capital. A simplifying assumption that is consistent with general equilibrium models (Cassing and Warr 1985) and CGE models (e.g., Kimbell and Harrison 1984).

A4. The endowments of labor are fixed to a region and by occupation. The assumption of a fixed endowment is consistent with the short-term analysis in a static CGE model. ${ }^{4}$ In truth, the endowment of labor may be variable because of migration, retirements, entrants into the labor force, and changes in out-of-state commuting patterns. It seems likely that most of these effects will be small and largely independent of any subsidy. Some note that, at least in theory, labor migration may play a role in the outcome of state economic development policies. If state-to-state migration were included, then the empirical literature suggests that

\footnotetext{
${ }^{2}$ Under the Johansen form, there is no need for calibration. The reason is that the variables are specified as proportionate changes, rather than levels. In other words, there is no need to solve for an equilibrium price level. ${ }^{3}$ Although enterprises in non-traded industries that are located next to political boarders may sell to residents from neighboring political jurisdictions, the assumption here is that these sales are small in relation to total sales within the state. Moreover, industries will be selected as non-traded only if they exhibit a relatively small percentage of trade across boundaries.

4Some developers of input-output models assume perfectly mobile labor. This assumption seems plausible. However, there is a lack of empirical evidence on the most likely assumption on migration, especially when considering aggregate migratory shifts by skill level. Some may point towards the AFDC literature on state-to-state migration. However, the literature provides little evidence of state-to-state migration for this low income group (Hanson and Hartman 1984; Levine and Zimmerman 1996). Thus the short-run nature of the model and the lack of empirical evidence led this research to first examine the case of perfectly inelastic labor supply.
} 
higher-skilled labor is more likely to migrate than lesser skilled labor (Borjas, Bronars, and Trejo 1992). However, the empirical literature does not provide enough guidance to construct separate elasticity estimates of migration by skill level. In addition, little empirical information exists on how swiftly workers change occupations in response to wage rates. Because of the paucity of empirical literature, the assumption of a fixed endowment of labor by region and occupation was chosen.

A5. The endowment of capital owned by residents within the state is fixed and can be sold to enterprises that locate within the state or outside of the state. The assumption recognizes that owners are not bound to invest capital within their own state. Instead, owners can freely choose to invest in capital equipment for enterprises in other states.

\section{EQUATIONS}

The equations of the model are listed within the following section. Tables 2 and 3 list variables and parameters for the model.

\section{HOUSEHOLD INCOME AND EXPENDITURES}

$$
\begin{aligned}
& \hat{M}_{m}=\sum_{f=1}^{L} \Theta_{m f}\left(\hat{w}_{f}=\hat{L}_{m f}\right)+\sum_{i=1}^{21} \Theta_{\text {miz }}\left(\hat{w}_{i z}+\hat{z}_{z}\right)+ \\
& \sum_{i=1}^{21}\left[\Theta_{m w i}\left(\hat{w}_{k}=\hat{k}_{m w i}\right)+\Theta_{\text {mrowi }}\left(\hat{w}_{k}+\hat{k}_{\text {mrowi }}\right)\right]+\Theta_{m G} \hat{G}
\end{aligned}
$$

$$
\left(\frac{\hat{M}}{P}\right)_{m}=\hat{M}_{m}-\sum_{j=1}^{21} \Theta_{m j} \hat{P}_{j}
$$

$$
\begin{aligned}
\hat{M} & =\sum_{m=1}^{3} \mu_{m} \hat{M}_{m} \\
& \left(\frac{\hat{M}}{P}\right)=\hat{M}-\sum_{j=1}^{21} \sum_{m=1}^{3} \theta_{m j} \hat{P}_{j}
\end{aligned}
$$

(5) $\quad \hat{C}_{m j}=\hat{M}_{m}-\hat{P}_{j}$

There are three household types (m=low-, medium-, and high-income households). Each household earns income from factor payments to endowments of labor and capital. Equation (1) is nominal income for each household type. Equation (2) is real income for group $\mathrm{m}$ and equals nominal income $\left(\mathrm{M}_{\mathrm{m}}\right)$ minus a group specific price index $\left(\hat{P}_{m}=\sum_{i=1}^{21} \Theta_{m j} \hat{P}_{j}\right)$. Equations (3) and (4) are aggregate nominal income and aggregate real income where aggregate nominal income equals the share weighted sum of proportionate changes in nominal income by group. Aggregate real income equals aggregate nominal income less the percent change in the price index for all groups. Equation (5) equals consumer demand for 
each commodity $(j=1, \ldots, 21)$ and household type. For representation of the utility maximizing behavior, a Cobb-Douglas utility function is adopted.

\section{FACTOR DEMANDS, FACTOR PRICES, AND} THE ZERO PROFIT CONDITION

$$
\begin{aligned}
& \hat{k}_{i}=\hat{X}_{i}-\sigma_{i}\left(\hat{w}_{i k^{\prime}}-\sum_{f=1}^{K+L} \omega_{i f}^{p} \hat{w}_{i f}^{\prime}\right) \\
& \hat{z}_{i}=\hat{X}_{i}-\sigma_{i}\left(\hat{w}_{i z}-\sum_{f=1}^{K+L} \omega_{i f}^{p} \hat{w}_{i f}\right) \\
& \hat{l}_{i f}=\hat{X}_{i}-\sigma_{i}\left(\hat{w}_{i l^{\prime}}-\sum_{f=1}^{K+L} \omega_{i f}^{p} \hat{w}_{i f}^{\prime}\right) \\
& \hat{x}_{i j}-\hat{X}_{i} \\
& \hat{w}_{i f}=\hat{s}_{i f}+\hat{w}_{f}-\epsilon{ }_{i \lambda R D} R D_{i}-\epsilon_{i \lambda E D} E \hat{D}_{i} \\
& \left.\hat{p}_{i}+\hat{X}_{i}=\sum_{j=1}^{21} \Theta_{i f}^{p}\left(\hat{p}_{j}+\hat{x}_{i j}\right)+\sum_{f=1}^{L} \theta_{i f}^{p}\left(\hat{w}_{f}+\hat{s}_{i f}\right)+\hat{l}_{i f}\right) \\
& +\Theta_{i k}^{p}\left(\hat{w}_{k}+\hat{s}_{i k}+\hat{k}_{i}\right)+\theta_{i z}^{p}\left(\hat{w}_{i z}+\hat{\alpha}_{i z}+\hat{z}_{i}\right)
\end{aligned}
$$

Equations (6), (7), and (8) are proportionate changes in variable capital, specific capital, and labor by occupation. The number of occupations (L) equals 18. ${ }^{5}$ The factor demands are represented by a CES production function and assume cost minimizing behavior on the part of producers. Equation (9) equals intermediate inputs and is derived from a Leontief production function. ${ }^{6}$ Equation (10) says that the change in factor prices equals proportionate changes in the factor tax deduction, the price of the factor, and the technological change parameter. Equation (11) gives the zero profit condition, which is an accounting identity documenting the distribution of revenue to all factors. The zero profit condition states that the proportionate change in total revenue equals share weighted changes in each factor.

\section{MARKET CLEARING CONDITIONS FOR OUTPUTS AND FACTORS}

$$
\hat{\mathrm{X}}_{\mathrm{i}}=\sum_{\mathrm{j}=1}^{21} \phi_{\mathrm{if}}^{\mathrm{P}} \hat{\mathrm{x}}_{\mathrm{if}}+\sum_{\mathrm{m}=1}^{3} \phi_{\mathrm{mi}}^{\mathrm{c}} \hat{\mathrm{C}}_{\mathrm{mi}}+\phi_{\mathrm{i}} \hat{\mathrm{e}}_{\mathrm{i}}
$$

${ }^{5}$ The distinction between goods-producing and services-producing industries does not result in a similar distinction in occupations. Some manufacturing enterprises carry out services-producing functions. Consequently, these manufacturing enterprises hire labor from occupations associated with services-producing industries (e.g., engineers and accountants).

${ }^{6}$ The demand for intermediate inputs is a function of output because a Leontief production function assumes that output is produced in fixed proportion to the inputs. Under such a case, the cost minimizing demand for an input depends only upon the level of output. 


$$
\begin{aligned}
& \hat{\mathrm{L}}_{\mathrm{f}}=\sum_{\mathrm{i}=1}^{21} \phi_{\mathrm{if}}^{\mathrm{p}} \hat{\mathrm{I}}_{\mathrm{if}} \\
& \hat{k}_{\text {mrowi }}=\epsilon_{w k}^{\text {mrowi }} \hat{w}_{w k}+\epsilon_{\text {rowk }}^{\text {mrowi }} \hat{w}_{\text {rowk }} \\
& \hat{k}_{\mathrm{mwi}}=\epsilon_{\mathrm{wk}}^{\mathrm{mwi}} \quad \hat{\mathrm{w}}_{\mathrm{wk}}+\epsilon_{\text {rowk }}^{\mathrm{mwi}} \hat{\mathrm{w}}_{\text {rowk }} \\
& \hat{\mathrm{K}}=\sum_{\mathrm{i}=1}^{21} \sum_{m=1}^{3}\left(\kappa_{m w i} \hat{\mathrm{k}}_{m w i}+\kappa_{\text {mrowi }} \hat{\mathrm{k}}_{\text {mrowi }}\right) \\
& \hat{G}=\sum_{i=1}^{21} \sum_{f=1}^{L} \theta_{\text {gif }}\left(-\left(\frac{S_{i f}}{1-S_{\text {if }}}\right) \hat{s}_{\text {if }}+\hat{W}_{f} \hat{\mathrm{I}}_{\text {if }}\right) \\
& +\sum_{i=1}^{21} \Theta_{g i k}\left(-\left(\frac{S_{i k}}{1-S_{i k}}\right) \hat{s}_{i k}+\hat{w}_{k} \hat{k}_{i}\right) \\
& +\sum_{\mathrm{i}=1}^{21} \Theta_{\mathrm{gi \pi}}\left(-\left(\frac{\alpha_{\mathrm{iz}}}{1-\alpha_{\mathrm{iz}}}\right) \hat{\alpha}_{\mathrm{iz}}+\hat{\mathrm{w}}_{\mathrm{iz}} \hat{\mathrm{z}}_{\mathrm{i}}\right) \\
& +\sum_{i=1}^{21} \Theta_{i R D} R \hat{D}_{i}-\sum_{i=1}^{21} \theta_{i E D} E \hat{D}_{i}
\end{aligned}
$$

Equations (12) through (17) list market clearing conditions and government expenditures. Equation (12) lists the market clearing condition for output. The equation states that the proportionate change in output equals the sum of share weighted changes in demand for intermediate inputs, consumption, and net trade of the good. Equation (13) sets the proportionate change in the endowment for labor equal to the sum of share weighted changes in demand for labor. Equations (14) and (15) state that the proportionate change in the quantity of capital supplied by group $(\mathrm{m})$ within the state to enterprises outside and within the state equals elasticity weighted changes in the price of capital within the state and outside of the state. ${ }^{7}$ Equation (16) states that the proportionate change in the resource endowment of capital equals the share weighted changes in capital supplied from within and outside the state. The government budget constraint depicted by equation (17) equates corporate income taxes, factor tax deductions, and research and development and labor training subsidies with a lump sum tax on consumers.

\section{GINI COEFFICIENT}

$$
\text { Gini }=\hat{o}_{g N} \hat{N}+\delta_{g m} \hat{m}+\delta_{g 1}\left(\hat{m}_{1}+\hat{l}_{1}\right)+\delta_{g 2}\left(\hat{m}_{2}+\hat{l}_{2}\right)+\delta_{g 3}\left(\hat{m}_{3}+\hat{l}_{3}\right)
$$

Proportionate change in the Gini coefficient (18) equals the weighted sum of proportional changes in the population of income earners, in average per 
capita real income, in per capita real income for each group, and in the weight for each income group.

TABLE 2

Variable List for the CGE Model

\begin{tabular}{|c|c|c|c|}
\hline Variable & Variable Names & Exogenous & Endogenous \\
\hline $\mathrm{M}_{\mathrm{m}}$ & Aggregate nominal income by group $\mathrm{m}$ & & 3 \\
\hline$w_{f}$ & Price of labor in occupation $\mathrm{f}$, in industry $\mathrm{i}$ & & 18 \\
\hline $\mathrm{L}_{\mathrm{mf}}, \mathrm{L}_{\mathrm{f}}$ & Resource endowment of labor in occupation $\mathrm{f}$ & 18 & \\
\hline $\mathrm{w}_{\mathrm{iz}}$ & Price of the specific factor for industry $i$ & & 21 \\
\hline$z_{i}$ & Quantity of specific factor in sector i & 21 & \\
\hline $\mathrm{w}_{\mathrm{k}}$ & Price of capital after assumption $A 3$ is imposed & 1 & \\
\hline$k_{\text {mwi }}^{n}$ & Capital supplied within the state by owners within the state & 63 & \\
\hline$k_{\text {mrowi }}$ & Capital supplied outside the state by owners outside the state & 63 & \\
\hline & Government budget constraint & & 1 \\
\hline$(\mathrm{M} / \mathrm{P})_{\mathrm{m}}$ & Aggregate real income by group $\mathrm{m}$ & & 3 \\
\hline $\mathrm{p}_{\mathrm{i}}$ & Price of goods and services & 18 & 3 \\
\hline M & Aggregate nominal income & & 1 \\
\hline$(\mathrm{M} / \mathrm{P})$ & Aggregate real income & & 1 \\
\hline $\mathrm{C}_{\mathrm{mi}}$ & Consumer demand for good $\mathrm{j}$ by household $\mathrm{m}$ & & 63 \\
\hline$k_{i}$ & Quantity of capital demanded by sector i & & 21 \\
\hline$X_{i}^{2}$ & Output from industry $\mathrm{i}$ & & 21 \\
\hline $\mathrm{w}_{\mathrm{ik}}{ }^{\prime}, \mathrm{w}_{\mathrm{if}}{ }^{\prime}$, & & & \\
\hline $1_{i j} w_{i z}, w_{i l}^{\prime}$ & Effective price of input & & 420 \\
\hline $\begin{array}{l}l_{\text {if }} \\
\mathbf{x}_{\text {ii }}\end{array}$ & $\begin{array}{l}\text { Quantity demanded of labor from industry } 1 \text { of occupation } t \\
\text { Quantity of intermediate input demanded by sector } i \text { of factor }\end{array}$ & & 378 \\
\hline$s_{i f}, s_{i k}$ & Factor tax deduction on capital or labor in sector $i$ & 378 & 441 \\
\hline $\mathrm{RD}_{\mathrm{i}}$ & Research and development subsidy in sector i & 21 & \\
\hline $\mathrm{ED}_{\mathrm{i}}$ & Labor training subsidy in sector i & 21 & \\
\hline $\mathrm{i}_{\mathrm{z}}$ & Corporate income tax on sector i & 21 & \\
\hline$e_{j}$ & Excess demand for goods and services & 3 & 18 \\
\hline$w_{w k}$ & Price of capital inside the state & 1 & \\
\hline $\mathrm{w}_{\text {rowk }}$ & Price of out-of-state capital & 1 & \\
\hline $\mathrm{K}$ & Resource endowment of variable capital & 1 & \\
\hline Gini & Gini coefficient & & 1 \\
\hline $\mathrm{N}$ & Total number of income earners & & 1 \\
\hline $\mathrm{m}$ & Average per capita income & & 1 \\
\hline $\mathrm{m}_{1}, \mathrm{~m}_{2}, \mathrm{~m}_{3}$ & Per capita real income for each group & & 3 \\
\hline$I_{1}, I_{2}, I_{3}$ & Weight for each income group & & 3 \\
\hline Total & Total number of variables & 634 & 1419 \\
\hline
\end{tabular}

\section{DATA SOURCES}

Data for expenditure shares by consumers, cost shares for producers, share of income held by each group, and parameters for the Gini coefficient come from IMPLAN $^{8}$. Cost shares for labor also used price updated data from the 1980 Census of Population (U.S. Department of Commerce 1982) for occupational wage rates. The data for the elasticities of substitution and capital shares for each household type come from Scholz (1987). An industry occupation matrix constructed by the Wisconsin Department of Industry, Labor and Human Relations (since renamed the Department of Workforce Development) provided data for employment shares. The Wisconsin Department of Development (since renamed the Department of Commerce) provided data for expenditure shares on state funded research and development and labor training. The remaining parameters were calculated using some combination of the above data sources. 
TABLE 3

List of Parameters for the CGE Model

\begin{tabular}{|c|c|}
\hline Parameter & Parameter Names \\
\hline 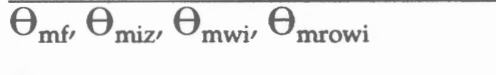 & $\begin{array}{l}\text { Shares of payments for capital (and labor) to income } \\
\text { within group } \mathrm{m}\end{array}$ \\
\hline$\stackrel{\Theta}{\mathrm{mG}}_{\mathrm{m}}$ & Share of government revenue to income for group $\mathrm{m}$ \\
\hline$\mu_{m}^{m j}$ & Share of income for group $\mathrm{m}$ to total income \\
\hline$\sigma_{\mathrm{i}}$ & Elasticities of substitution \\
\hline & Share of primary factor cost to total cost \\
\hline$\Theta p_{i j}$ & Share of cost of intermediate goods to total cost \\
\hline$\Theta p_{i f}, \theta p_{i k}, \theta p_{i z}$ & Share of cost of primary factor to total cost \\
\hline & $\begin{array}{l}\text { Industry, consumption and excess demand market shares } \\
\text { Share of capital (or labor) to total quantity of capital or labor }\end{array}$ \\
\hline$\epsilon_{\text {wk }}^{\operatorname{mrowi}}, \epsilon_{\text {rowk }}^{\text {mrowi, }} \epsilon_{\text {wk }}^{\mathrm{mwi}} \epsilon_{\text {rowk }}^{\mathrm{mwi}}$ & $\begin{array}{l}\text { Elasticities of the supply of capital from outside the state (row) } \\
\text { and within the state (w) in sector } i\end{array}$ \\
\hline$\kappa_{\text {mwi }}, \kappa_{\text {mrowi }}$ & $\begin{array}{l}\text { Share of capital supplied by household type } \mathrm{m} \text { in sector i from } \\
\text { within (w) and outside the state (row) }\end{array}$ \\
\hline$\Theta_{\text {gif }}, \theta_{\text {gik }}$ & $\begin{array}{l}\text { Share of payments on tax credits for purchases of labor and } \\
\text { variable capital to revenue from lump sum tax on individuals }\end{array}$ \\
\hline$\Theta_{\text {gi } \pi}$ & $\begin{array}{l}\text { Share of revenue from a tax on business profits to revenue } \\
\text { from a lump sum tax on individuals }\end{array}$ \\
\hline$\Theta_{\mathrm{iRD}}, \theta_{\mathrm{iED}}$ & $\begin{array}{l}\text { Share of payments for research and development and labor } \\
\text { training subsidies }\end{array}$ \\
\hline$\delta_{\mathrm{gN}}{ }^{*}$ & $\begin{array}{l}\text { Elasticity of the Gini coefficient with respect to the aggregate } \\
\text { number of workers }\end{array}$ \\
\hline$\delta_{\mathrm{gm}}$ & $\begin{array}{l}\text { Elasticity of the Gini coefficient with respect to average per } \\
\text { capita real income }\end{array}$ \\
\hline$\delta_{\mathrm{g} 1}, \delta_{\mathrm{g} 2}, \delta_{\mathrm{g} 3}$ & $\begin{array}{l}\text { Elasticity of the Gini coefficient with respect the weight placed } \\
\text { on each income group (ii) and per capita income for each group } \\
\left(m_{i}\right), i=\{1,2,3\}\end{array}$ \\
\hline
\end{tabular}

*See Hirasuna (1994) for further information on the elasticities for the Gini Coefficient.

\section{AGGREGATING INDUSTRIES}

For purposes of this analysis, the state economy is broken into twenty-one industries. The appendix lists the names for the industries along with example enterprises. The listing of criteria in Table $1 \mathrm{~A}$ of the appendix identifies which industries are traded and which are non-traded. ${ }^{9}$ The aggregated industries were chosen with two goals. One goal is to accurately represent the economy with a minimum number of industries. Another goal is to select a set of industries with characteristics that are often cited by professionals in the field of economic development working for state and local departments of development.

In order to achieve these goals, the industries were aggregated based on seven different criteria: (1) industries that are explicitly considered in the hypotheses; (2) industries with similar Standard Industrial Code (SIC) classifications; (3) industries with large employment bases; (4) high-growth industries; (5) industries with different occupational skill requirements; (6) traded industries; and (7) industries that sell all of their output to other producers.

The separation of traded, non-traded, and tourism industries is important for the subsequent analysis. Eighteen of the industries whose prices are set exogenously under the small open economy assumption (A3) are traded. Two are non${ }^{8}$ Impact Analysis for Planning (IMPLAN), Version 91-f, St. Paul, MN. 
traded industries, which implies that their prices are determined by the intersection of within-state supply and demand curves (assumption A1). ${ }^{10}$ The tourism industry is traded, but is price endogenous due to assumption A2.

\section{The Subsidies}

This experiment includes a capital subsidy, labor subsidy, research and development subsidy, and labor training subsidy. Comparisons of the subsidies are made based on the percent change in aggregate real income and income inequality. The change in income inequality is measured by percent changes in the Gini coefficient.

For purposes of analysis it is assumed that all of the state subsidies equal approximately $\$ 2$ million, which serves as a rough approximation. States typically allocate a specific dollar amount for development purposes. An alternative way to compare subsidies is on the basis of a percent change in subsidy rate. That way, an elasticity could be calculated depicting the percent change in income per percent change in the subsidy rate. The dollar amount was chosen because of its greater verisimilitude.

The analysis also assumes that all subsidies are industry specific. The subsidies are directed to individual firms within specific industrial classifications. It is recognized that services-producing components are often a part of manufacturing entities. Nonetheless, state policy typically focuses on industrial groupings rather than occupational classes (e.g., research and development subsidies to high-technology manufacturing, or capital subsidies to manufacturing). An exception might be that state labor training subsidies may also be focused on occupations (e.g., technical college programs). In this analysis, the economic development-labor training incentive is directed to firms rather than individuals.

\section{Factor Tax Deductions on Capital and Labor}

Factor tax deductions decrease cost by lowering the price paid by producers. The factor tax deduction on capital is placed on variable capital and the factor tax deduction on labor is placed in equal percentages across all occupations within the industry sector.

A factor tax deduction on capital might be provided to firms through grants, reduced interest rates, or favorable repayment terms. Such subsidies decrease cost through a lower price for capital. Decreased cost results in increased output until the subsidized industry marginal cost equals price. Increased output increases demand for intermediate inputs from other industries and primary factors. The end result is increased wages and increased income in the hands of workers and consumers. The prices of non-traded and tourism items increase as a result of increased spending by consumers. The magnitude of changes in aggregate income and wage inequality depend on the composite magnitudes of elasticities and shares specified in the model.

${ }^{9}$ All industries that import and export less than 10 percent of their revenue are considered non- traded.

${ }^{10}$ The non-traded industries are non-traded producer services and non-traded consumer services. 
The factor tax deduction on labor might be provided to employers through a subsidy for employees (e.g., a targeted jobs tax credit). This deduction can lubricate market processes by diminishing historical or institutional barriers, by compensating for a lack of a skilled labor pool, or by neutralizing resource misallocation caused by immobile labor or wage rigidities. The subsidy decreases the price of labor and costs to the subsidized industry. The decreased cost results in increased output and, ultimately, increased income in the hands of individuals within the state.

\section{Research and Development and Labor Training Subsidies}

Both research and development subsidies and labor training subsidies differ from a factor tax deduction. Rather than reducing factor costs, research and development and labor training subsidies lower cost by developing improved capital or more effective labor. As in the factor tax deductions, the decreased cost results in increased output and increased demand for intermediate inputs and primary factors. Increased demand for primary factors results in increased income and increased demand for consumer items. The prices of non-traded and tourism items increase and payments to primary factors once again increase.

The research and development subsidies are assumed to give rise to capital-using technical change. Such a subsidy may be a direct public grant for product research and development or a special tax deduction for this purpose. Labor training subsidies include customized labor training or state funded training programs directed at specific businesses or industries. This study assumes that state government subsidizes private enterprises to train their own labor. Labor training is assumed to result in labor-using technical change. These subsidies provide workers with skills, which shifts out the marginal physical product of labor.

Because of the paucity of empirical estimates on the impacts of research and development subsidies and labor training subsidies, it is assumed that either subsidy results in a 10 percent increase in the productivity of capital or labor. For purposes of the policy experiment, research and development subsidies are modeled by setting $\epsilon_{\mathrm{i} \lambda \mathrm{RD}} R \mathrm{D}_{\mathrm{i}} \mathrm{i}$ equal to 0.1 in equation (10). For the labor training subsidy, $\epsilon_{\mathrm{i} \lambda E \mathrm{D}} E D_{\mathrm{i}} \mathrm{i}$ also equals 0.1 .

By the nature of the Johansen form of general equilibrium modeling, the percent change in productivity is linear in its effects (Dixon et al. 1982). This implies that the preselected 10 percent change in $\epsilon_{\mathrm{i} \lambda \mathrm{ED}}\left(=\left(\partial \lambda_{\mathrm{il}} / \partial \mathrm{ED}_{\mathrm{i}}\right) \mathrm{ED}_{\mathrm{i}} / \lambda_{\mathrm{EDi}}\right)$ can be multiplied by a factor (call it $\alpha$ ) to represent a different level of productivity change. Correspondingly, changes in the level of income and income distribution can be multiplied by the same factor $(\alpha)$ to acquire the true percent changes in the level of income and income distribution.

Because of an assumed 10 percent increase due to a $\$ 2$ million public expenditure, comparisons within research and development subsidies and within labor training subsidies may be more appropriate than comparisons across subsidies. However, both assume the same expenditure, so given the assumption it is 
possible to make comparisons between research and development subsidies and labor training subsidies, as well as with factor tax deductions.

\section{RESULTS}

This section presents the results from comparing the impacts of subsidies between the manufacturing and traded services-producing sectors. Tables 4 and 5 list percent changes $\hat{i n}$ real income and wages. Each table lists the percent change in real income for three income groups-low $(<\$ 20,000$ per year), medium ( $\$ 20,000$ to $\$ 40,000$ per year), and high ( $>\$ 40,000$ per year). Percent changes in wages are listed for the three broad occupational categories-white-collar workers, blue-collar workers, and office and clerical workers.

The general conclusion of this analysis is that state subsidies awarded to traded services-producing industries will not necessarily decrease aggregate real income or raise income inequality in comparison to subsidies awarded to the manufacturing sector. In fact, all subsidies other than the factor tax deduction on capital yield a higher percent increase in aggregate real income when the subsidy is awarded to the traded services-producing sector rather than the manufacturing sector. Furthermore, subsidies to the manufacturing sector are inclined to increase income inequality in comparison to similar subsidies to the traded servicesproducing sector.

TABLE 4

Percent Changes In the Level of Income and Income Distribution From a Factor Tax Deduction on Capital and Labor Awarded to the Manufacturing and Traded Services-Producing Sectors

\begin{tabular}{lcccc}
\hline & \multicolumn{2}{c}{ Capital } & \multicolumn{2}{c}{ Labor } \\
\hline & \multicolumn{2}{c}{ Traded Services- } & \multicolumn{2}{c}{ Traded Services- } \\
& Manufacturing & Producing & Manufacturing & Producing \\
\hline [1] subsidy rate $\left(\mathrm{s}_{\mathrm{if}}{ }^{*}\right.$ 100) & 3.11 & 2.61 & 0.72 & 0.9 \\
Real Income & & & & \\
[2] Low & -0.20 & 0.35 & -0.10 & 0.34 \\
[3] Medium & 0.58 & 0.10 & 0.36 & 0.19 \\
[4] High & 0.49 & 0.65 & 0.23 & 0.31 \\
[5] Aggregate & 0.38 & 0.34 & 0.22 & 0.26 \\
[6] Gini Coefficient & 1.37 & 0.87 & 0.62 & -0.01 \\
Wages by Group & & & & \\
[7] Blue-collar & 1.20 & -0.19 & 0.73 & -0.16 \\
[8] White-collar & 0.50 & 0.60 & 0.23 & 0.47 \\
[9] Office and Clerical & -0.14 & 0.57 & -0.06 & 0.53 \\
[10] Aggregate & 0.42 & 0.29 & 0.26 & 0.32 \\
\hline
\end{tabular}




\section{TABLE 5}

Percent Changes in the Level of Income and Income Distribution Due to Productivity Enhancing Subsidies to the Manufacturing Sector and the Traded Services-Producing Sector

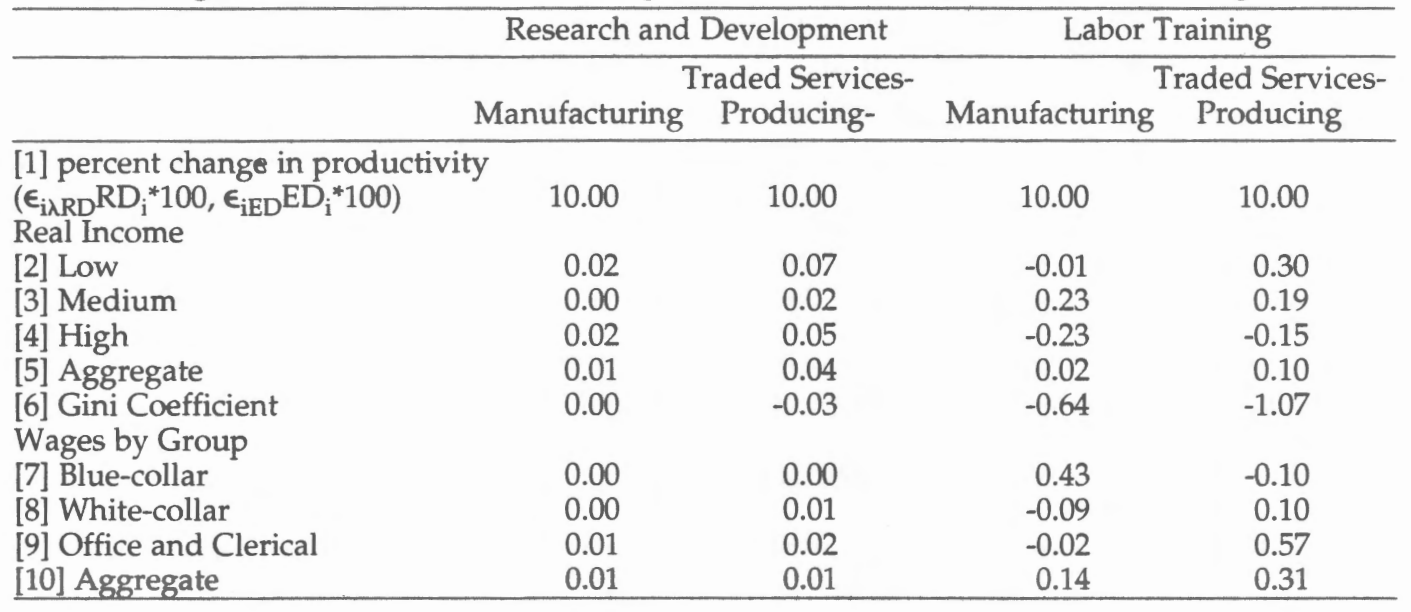

\section{A Factor Tax Deduction on Capital}

When awarded to the manufacturing sector, the factor tax deduction on capital increases aggregate real income by a larger percentage than any other subsidy. The increase in aggregate real income is 0.38 percent from the capital subsidy to manufacturing and 0.34 percent from the capital subsidy to traded services.

A This subsidy will raise income inequality when awarded to either sector. When a factor tax deduction on capital is awarded to the manufacturing sector, the Gini coefficient increases by 1.37 percent, which is larger than the 0.87 percent increase from a subsidy to the traded services-producing sector.

Much of the per capita income increase from the factor tax deduction on capital is in higher income groups. The percent change in wages reflects which group is the primary beneficiary of the subsidy. Capital subsidies to the manufacturing sector raise wages for blue-collar workers. Capital subsidies to the traded services-producing sector raise income for office and clerical workers. The percent increase in wages reflects increased demand for labor in occupations that are employed relatively more intensively in the subsidized sector.

If state policy makers are primarily concerned about increasing aggregate income, capital subsidies appear to be the most effective of those considered. If, however, their primary concern is income inequality, then capital subsidies tend to worsen the situation.

\section{A Factor Tax Deduction on Labor}

A factor tax deduction on labor to the traded services-producing sector increases aggregate real income by a larger percentage than similar subsidies awarded to the manufacturing sector. The percent change in aggregate real income is 0.26 percent in traded services and 0.22 percent in manufacturing. This subsidy increases income inequality when awarded to the manufacturing sector, 
but decreases income inequality slightly when awarded to the traded servicesproducing sector. In the first case the Gini coefficient increases by 0.62 percent, and in the second case it declines by -0.01 percent.

When awarded to the manufacturing sector, a factor tax deduction to labor increases income in the high and middle income groups, but results in a decline in income in the low income group. In contrast, when this subsidy is awarded to the traded services-producing sector, income increases in all three income groups, with the largest percent increase occurring in the low income group. A factor tax deduction on labor to the manufacturing sector raises wages for blue-collar workers. The same subsidy raises wages for office and clerical workers when applied to the traded services-producing sector.

\section{A Research and Development Subsidy}

A research and development subsidy raises aggregate real income by 0.01 percent when applied to the manufacturing sector and by 0.04 percent when applied to the traded services-producing sector. Of course, the effects would be larger if the real productivity increases were larger than those posited. There is no change in the Gini coefficient from a research and development subsidy awarded to the manufacturing sector. The Gini coefficient declines slightly when this subsidy is awarded to the traded services-producing sector. In both cases, the negligible change is due to small changes in the per capita real income of each group.

The research and development subsidy results in little change in wages by type of occupation. The largest change is 0.02 percent for office and clerical workers. This subsidy appears to be the least effective of those studied in producing an increase in aggregate real income. The results might differ, however, under other assumptions regarding general productivity increases or if there were significant differences in the productivity increases resulting from research and development investments in manufacturing versus investments in traded services.

\section{A Labor Training Subsidy}

A labor training subsidy that increases productivity by 10 percent tends to have a small effect on aggregate real income while decreasing income inequality. The effects of the subsidy would be larger if the productivity increases were larger than those posited. The labor training subsidy to the manufacturing sector increases aggregate real income by 0.02 percent. The labor training subsidy to the traded services-producing sector raises aggregate real income by 0.10 percent. Income inequality declines with a labor training subsidy to either sector. The Gini coefficient declines by 0.64 percent when the subsidy is applied to manufacturing and by -1.07 percent in the case of traded services.

A labor training subsidy tends to reduce relative incomes in higher income groups and increase incomes in middle income groups. This subsidy reduces the incomes of the lower income group when applied to manufacturing $(-0.01$ percent $)$ and increases the incomes of this group when applied to traded services-producing 
industries ( 0.30 percent). A labor training subsidy to the manufacturing sector tends to increase wages of blue-collar workers. In the traded services-producing sector, this subsidy increases wages for office and clerical workers.

\section{POLICY CONCLUSIONS}

The basic hypothesis, that public subsidies to services-producing industries result in smaller increases in aggregate real income and greater income inequality than similar subsidies applied to the goods-producing sector, is questionable. In fact, it is possible that some subsidies to traded services-producing industries increase aggregate real income more than those to manufacturing industries. Only a factor tax deduction on capital raises real income more when applied to manufacturing rather than to traded services. All of the other subsidies examined-a factor tax deduction on labor, a research and development subsidy, and a labor training subsidy-increase aggregate real income more when awarded to the traded services-producing sector. The evidence suggests that some subsidies to traded services can raise aggregate real income by more than those to manufacturers.

It is also possible that subsidies awarded to the traded services-producing sector may be more effective in reducing income inequality. Using Gini coefficient analysis, none of the economic development subsidies awarded to the manufacturing sector reduces income inequality more than the same subsidy to the traded services-producing sector.

The dilemma that often confronts policy makers is that they may be able to increase aggregate real income or reduce income inequality, but not both. ${ }^{11}$ In some cases, raising aggregate real income may result in increased income inequality. For example, a factor tax deduction to capital applied to manufacturing produces the highest increase in income and at the same time the largest increase in income inequality. In contrast, the largest decrease in income inequality is from a labor training subsidy to the traded services-producing sector. However, it produces relatively smaller increases in aggregate real income. A factor tax deduction on labor awarded to traded services-producing industries appears to be the closest thing to a compromise, resulting in an increase in aggregate real income and a small decrease in income inequality. Undoubtedly, some combination of policies will be necessary in meeting specific state economic development objectives.

This study cannot ensure the same result for every state that offers subsidies to traded services-producing industries. State economies differ in the type of traded industries present and the availability of capital and skilled labor within the state. The results may depend upon the state's fiscal policy. For

${ }^{11} \mathrm{~A}$ broader statement of the policy dilemma is the relationship between efficiency and equity. This study does not address efficiency in the first-best sense. In this model, where more than one distortion exists, increased income is not always obtained by reducing only one of the distortions (see Hirasuna 1994 and Goulder, Parry, and Burtraw 1996). Some may suggest that horizontal neutrality or equal treatment of like enterprises is an important equity and, for some cases, efficiency consideration. This research does not address the broader issue of neutrality, primarily because current subsidies for economic development and tax incentives to enterprises do not appear to remain consistent with neutrality. A useful experiment for a later study would be to examine the effect of horizontal neutrality in economic development subsidies and tax incentives on income and income inequality. 
example, subsidies financed by a sales tax on all items, including necessities, may increase income inequality. In addition, this study is a policy experiment free from complicating factors, such as movements in the exchange rate, decreased trade barriers, and changes in federal and state policy (e.g., welfare reform), which may alter the results. Nonetheless, it is clear that in some situations, subsidies to services-producing industries can play a positive role in economic development policy.

In context with previous work, this study raises further doubt whether economic development incentives to services-producing industries reduce aggregate real income and raise income inequality in comparison to similar subsidies to goods-producing industries. Services-producing industries are not necessarily stagnant in productivity gains and may under certain conditions reduce rising wage inequality. This study develops a plausible model of a state economy to suggest the possibility that subsidies to traded services-producing industries may increase aggregate real income and decrease income inequality in comparison to subsidies awarded to goods-producing industries.

\section{APPENDIX}

TABLE $1 \mathrm{~A}$

List of Industry Categories With Criteria Used for Selection and Example IMPLAN Industries

\section{Agriculture \\ Criteria used for selection: like SIC, declining growth rate, traded, producer-oriented \\ Dairy farm products \\ Poultry and eggs \\ Ranch fed cattle}

\section{Mining}

Criteria used for selection: like SIC, location quotient less than one, high wages, traded, producer-oriented

Iron ores

Copper ores

Lead and zinc ores

\section{Construction}

Criteria used for selection: like SIC, location quotient less than one, traded, producer-oriented

New residential structures

New industrial and commercial buildings

New highways and streets

\section{High-Tech Durables}

Criteria used for selection: like SIC, hightech industry, traded, producer-oriented Steam engines and turbines Industrial furnaces and ovens Semiconductors and related devices
Food, Textile, \& Clothing

Criteria used for selection: traded, producer-oriented

Meat packing plants

Cereal preparations

Leather gloves and mittens

\section{Other Nondurables}

Criteria used for selection: location quotient larger than one, traded, producer-oriented

Sawmills and planing mills

Fertilizers, mixing only

Paints and allied products

\section{Paper Products}

Criteria used for selection: like SIC, location quotient larger than one, high wages, traded, producer-oriented

Pulp mills

Paper mills

Envelopes

\section{Printing \& Publishing}

Criteria used for selection: like SIC, positive growth rates, location quotient less than one, traded, producer-oriented Newspapers

Book publishing

Commercial printing 
TABLE 1A (continued)

List of Industry Categories With Criteria Used for Selection and Example IMPLAN Industries

\section{M\&E Nonelectrical}

Criteria used for selection: like input structure, negative growth rates, location quotient larger than one, traded, producer-oriented

Special dies and tools and accessories Commercial laundry equipment

Motor vehicles

\section{Primary \& Fabricated Mineral}

Criteria used for selection: negative growth rates, traded, producer-oriented Glass and glass products

Brick and structural clay tile

Vitreous plumbing fixtures

\section{Electronic Durables}

Criteria used for selection: like SIC, negative growth rate, traded, producer-oriented Instruments to measure electricity Household refrigerators and freezers Electric lamps

Transportation \& Communication Criteria used for selection: like SIC, traded, producer-oriented Motor freight transport and warehousing Radio and TV broadcasting

Electric services

\section{Wholesale Trade}

Criteria used for selection: like SIC, positive growth rate, traded, producer-oriented

Recreational related wholesale Other wholesale trade

\section{Non-Traded Consumer Services}

Criteria used for selection: positive growth rates, non-traded, consumer-oriented Recreational related retail trade Bowling alleys and pool halls Nursing and protective care

\section{Lower Order Services}

Criteria used for selection: positive growth rate, traded, producer-oriented Credit agencies Laundry, cleaning, and shoe repair Portrait and photographic studios

\section{High-Tech Nondurables}

Criteria used for selection: like SIC, location quotient less than one, traded, producer-oriented

Industrial inorganic, organic chemicals

Plastics materials and resins

Organic fibers, non cellulosic

\section{Professional Services}

Criteria used for selection: positive growth rates, high wages, traded, producer-oriented Security and commodity brokers Computer programming services Engineering and architectural services

\section{Non-Traded Producer Services}

Criteria used for selection: positive growth rates, non-traded, producer-oriented Insurance carriers

Real estate

Photofinishing, commercial photography

\section{Tourism}

Criteria used for selection: positive growth rate, location quotient less than one, traded (but price endogenous)

Hotels and lodging places

Eating and drinking places

Commercial sports except racing

\section{Health \& Human Services}

Criteria used for selection: like SIC, positive growth rates, traded, consumer-oriented

Hospitals

Colleges, universities, and schools

Other nonprofit organizations

\section{Government \& Specialty Industries}

Criteria used for selection: like SIC, traded

U.S. postal services

Other federal government enterprises Inventory valuation adjustment 
TABLE 1B

The 18 Occupational Categories Chosen for the Model

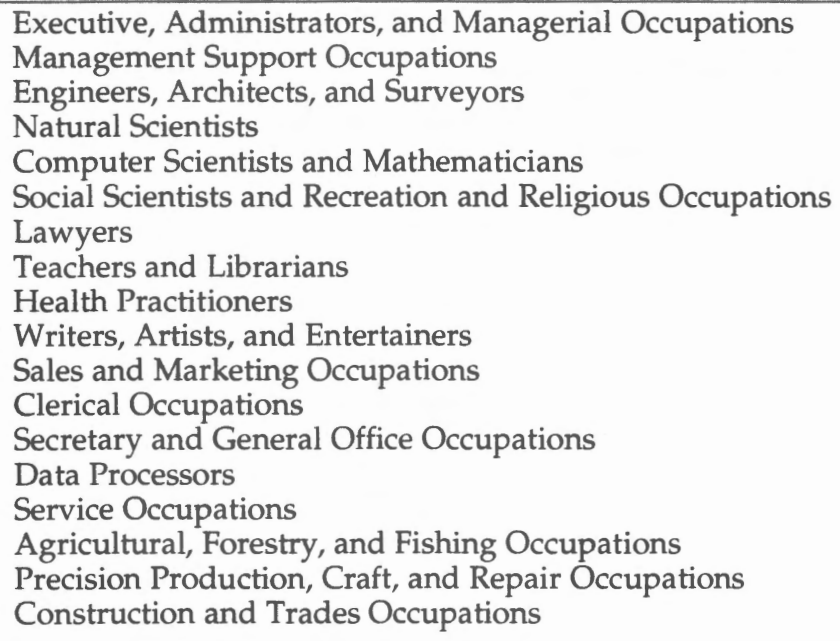

\section{REFERENCES}

Baumol, W.J., S.A. Batey Blackman, and E.N. Wolff. "Unbalanced Growth Revisited: Asymptotic Stagnance and New Evidence." American Economic Review 75 (1985), 806- 817.

Berman, E., J. Bound, and Z. Griliches. "Changes in the Demand for Skilled Labor Within U.S. Manufacturing Industries: Evidence from the Annual Survey of Manufacturing." Working paper No. 4255, National Bureau of Economic Research, 1993.

Beyers, W.B. "Trends in Service Employment in Pacific Northwest Counties: 19741986." Growth and Change 22 (1991), 27-49.

Bhagwati, J., and V.H. Dehejia. "Freer Trade and Wages of the Unskilled-is Marx Striking Again?" In J. Bhagwati and M.H. Kosters (eds.) Trade and Wages: Leveling Wages Down? Washington, D.C.: AEI Press, 1994.

Bluestone, B., and B. Harrison. The Deindustrialization of America. New York: Basic Books, 1982.

. "The Great American Jobs Machine: The Proliferation of Low Wage Employment in the U.S. Economy." Study prepared for the Joint Economic Committee, 1986.

Borjas, G.J., S.G. Bronars, and S.J. Trejo. "Self-Selection and Internal Migration in the United States." Journal of Urban Economics 32 (1992), 159-185.

Bound, J., and H.J. Holzer. "Industrial Shifts, Skills Levels, and the Labor Market for White and Black Males." The Review of Economics and Statistics 75 (1993), 387-396.

Bound, J., and G. Johnson. "Changes in the Structure of Wages in the 1980's: an Evaluation of Alternative Explanations." The American Economic Review 82 (1992), 371-392. 
Burtless, G. "International Trade and the Rise in Earnings Inequality." Journal of Economic Literature 33 (1995), 800-816.

Cassing, J.H., and P.G. Warr. "The Distributional Impact of a Resource Boom." Journal of International Economics 18 (1985), 310-319.

Computer Science and Telecommunications Board, National Research Council. Information Technology in the Service Society: a Twenty-first Century Lever. Washington, D.C.: National Academy Press, 1994.

Cutler, D., and L.F. Katz. "Rising Inequality in the Distribution of Income and Consumption in the 1980's." The American Economic Review: Papers and Proceedings of the 104th Annual Meeting 82 (1992), 546-551.

Davidson, C., and M. Reich. "Income Inequality: an Inter-industry Analysis." Industrial Relations 27 (1988), 263-286.

Dixon, P.B., B.R. Parmenter, J. Sutton, and D.P. Vincent. ORANI: a Multisectoral Model of the Australian Economy. New York: North-Holland Publishing Company, 1982.

Freeman, R.B. “Are Your Wages Set in Beijing?" Journal of Economic Perspectives 9 (1995), 15-32.

Freeman, R.B., and L.F. Katz. "Rising Wage Inequality: The United States vs. Other Advanced Countries." In R.B. Freeman (ed.) Working Under Different Rules. New York: Russell Sage Foundation, 1994.

Gittleman, M. "Earnings in the 1980's: an Occupational Perspective." Monthly Labor Review 117 (1994), 16-27.

Goulder, L.H., I.W.H. Parry, and D. Burtraw. "Revenue-Raising vs. Other Approaches to Environmental Protection: the Critical Significance of Preexisting Tax Distortions." NSF Grant 9310362, 1996.

Grubb, N.W., and R.H. Wilson. "Trends in Wage and Salary Inequality, 1967-88." Monthly Labor Review 115 (1992), 23-39.

Haigh, R.W. Investment Strategies and the Plant-location Decision: Foreign Companies in the United States. New York: Praeger Publishers, 1989.

Hanson, R.L. "Bidding for Business: A Second War Between the States?" Economic Development Quarterly 7 (1993), 183-198.

Hanson, R.L., and J.T. Hartman. “Do Welfare Magnets Attract?" Discussion Paper No. 1028-94, Institute for Research on Poverty, February 1994.

Hirasuna, D.P. "Changes in the Level of Income and Income Distribution Due to a Growth in Services-producing Employment: an Examination of Some State Economic Development Policies." Ph.D. dissertation, Department of Agricultural and Applied Economics, University of Wisconsin-Madison, 1994. Isserman, A.M. "State Economic Development Policy and Practice in the United States: a Survey Article." International Regional Science Review 16 (1994), 49-100. Juhn, C., K.M. Murphy, and B. Pierce. "Wage Inequality and the Rise in Returns to Skill." Journal of Political Economy 101 (1993), 410-442. 
Kimbell, L.J., and G.W. Harrison. "General Equilibrium Analysis of Regional Fiscal Incidence." In H.E. Scarf (ed.) Applied General Equilibrium Analysis. New York: Cambridge University Press, 1984.

Levine, P.B., and D.J. Zimmerman. "An Empirical Analysis of the Welfare Magnet Debate Using the NLSY." Discussion paper No. 1098-96, Institute for Research on Poverty, July 1996.

Murphy, K.M., and F. Welch. "Occupational Change and the Demand for Skill, 1940-1990." American Economic Review 83 (1993), 122-126.

Oregon Economic Development Commission. Getting it Right in Oregon: Biennial Report. Salem, 1995.

Parsley, D.C., and S.J. Wei. "Convergence to the Law of One Price Without Trade Barriers or Currency Fluctuations." Working Paper No. 5654, National Bureau of Economic Research, 1996.

Piore, M.J. Beyond Individualism. Cambridge: Harvard University Press, 1995.

Porterfield, S.L., and G.C. Pulver. "Exports, Impacts and Location of Services Producers." International Regional Science Review 14 (1991), 41-59.

Sachs, J.D., and H.J. Shatz. "Trade and Jobs in U.S. Manufacturing." Brookings Papers on Economic Activity 1 (1994), 1-84.

Scholz, J.K. "Documentation for 1983 General Equilibrium Data." Unpublished manuscript, 1987.

Stabler, J.C., and E.C. Howe. "Service Exports and Regional Growth in the Postindustrial Era." Journal of Regional Science 28 (1988), 303-315.

U.S. Department of Commerce, Bureau of the Census. U.S. Census of Population and Housing, 1980. Washington, D.C.: Government Printing Office, 1982. . Economic and Statistics Administration, Bureau of Economic Analysis, Regional Economic Measurement Division. Regional Economic Information System (REIS) CD-ROM, 1969-1993. Washington, D.C., 1995.

Washington State Community, Trade and Economic Development. Economic Diversification and Targeted Sectors Report: a Report to the Legislature. Olympia, 1996.

Wood, Adrian. North-South Trade, Employment and Inequality: Changing Fortunes in a Skill Driven World. New York: Oxford University Press, 1994. 